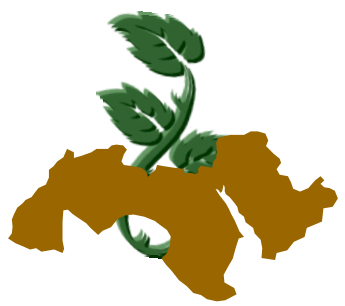

\title{
TOWARDS AN INTEGRATED CONTROL OF SESAME (SESAMUM INDICUM L.) CHARCOAL ROT CAUSED BY MACROPHOMINA PHASEOLINA (TASSI) GOID
}

\author{
Ibrahim, M.E. ${ }^{1}$ and A.M. Abdel-Azeem ${ }^{2}$ \\ 1- Department of Geological and Biological Sciences, Faculty of Education, University of Suez \\ Canal, Al-Arish, Egypt. \\ 2- Department of Botany, Faculty of Science, University of Suez Canal, Ismailia, 41522, Egypt
}

[41]

Keywords: Macrophomina phaseolina, Charcoal Rot, Sesame, Solarization, Amendment, Fungal antagonists.

\begin{abstract}
Soil solarization in combination with fungal antagonists and soil amendments has been subjected to evaluation as a potential disease management strategy for the control of charcoal rot of sesame caused by Macrophomina phaseolina (Tassi) Goid. Solarization alone or in combination with Trichoderma pseudokoningii and Emericella nidulans singly or in mixed inocula reduces disease incidence from $30 \%$ (control) to $80 \%, 91 \%$, $82 \%$ and $85 \%$ respectively. It is noted that while pairing improved the biocontrols potentiality of $E$. nidulans by increasing the number of healthy plants in both unsolarized and solarized soils it leads to decrease in the biocontrol potentiality of T. pseudokoningii. On the other hand the combination of solarization with soil amendment with $\mathrm{Eu}$ calyptus powdered leaves showed a synergistic effect by increasing number of healthy plants from $65 \%$ in amended unsolarized soil to $77 \%$ in amended solarized soil.
\end{abstract}

\section{INTRODUCTION}

Macrophomina phaseolina (Tassi) Goid. a soil borne fungus causes charcoal rot of roots and lower stem. The fungus can infect about 500 plant species in more than 100 families throughout the world (Mihail \& Taylor 1995 and Srivastava et al 2001). It is of high incidence in Egypt especial- ly during the hot period. In addition to root and stem root it causes in sesame (Sesamum indicum L.) early maturation, chlorosis and incomplete capsule filling (Wyllie, 1988). M. phaseolina survives as microsclerotia in the soil and infected plant debris. These microsclerotia serve as the primary source of inoculum and have been found to persist in the soil up to three years (Cloud and Rupe, 1991) but their survival is greatly reduced in wet soils.

Strategies of effective and economic disease management of charcoal rot are still inadequate. Management of charcoal rot requires integrated strategies that either reduce the population of microsclerotia in the soil or prevent infection. From an environmental point of view soil heating is a more acceptable method of enhancing efficacy of antagonistic strains of microbes against charcoal rot and many other plant pathogens. It can be accomplished in warm climates by solarization. This involves covering moistened field soil with transparent polyethylene sheets during the hot season causing an increase in soil temperature up to 45 ${ }^{\circ} \mathrm{C}$. The resulting high soil temperature can reduce diseases caused by several soil borne pathogens including nematodes, fungi and bacteria (Ramirez-Villapudua \& Munnecke, 1988; Satour et al 1989; Osman, 1990; Sarhan, 1990; Ali et al 1990; Davis, 1991; Melero-Vara et al 1995; Chellemi et al 1997; Lodha et al 1997 and Pinkerton et al 2000). Although soil temperatures attained by solarization may be sufficiently high to directly kill propagules of some pathogens present in the upper soil layers, the efficacy declines with soil depth (Katan, 1981), and therefore a combi- 
nation with other control measures is often necessary for improving the efficacy of soil solarization (Washington et al 2003). Improving of solarization can be accomplished by soil amendment with organic fertilizer or using antagonistic fungi.

The objective of the present investigation is to compare the efficacy of solarization alone and in combination with other means to control charcoal rot by Macrophomina phaseolina. These combinations comprised: the use of antagonistic fungi and amendment of soil with Eucalyptus leaves.

\section{MATERIALS AND METHODS}

\section{Experimental design}

An experiment consisted of two treatments namely, solarized (mulched with $0.9 \mathrm{~mm}$ thick transparent polyethylene sheets) and unmulched (exposed to direct sun-light) was conducted in the Botanical Garden of Faculty of Science, Suez Canal University at Ismailia in an artificially infested site with $M$. phaseolina. The site was divided into two plots $\left(10 \mathrm{~m}^{2}\right.$ each) in which both plots were further divided into five sections each measuring 1 x $2 \mathrm{~m}$. All experiments were repeated twice in the two consecutive seasons 2003 \& 2004 in which the effect of each of solarization, fungal antagonists, and soil amendment with Eucalyptus leaves alone and/ or in combination on the viability of inoculum of $M$. phaseolina were studied. Eucalyptus leaves were dried at $60{ }^{\circ} \mathrm{C}$ for $48 \mathrm{hr}$ and powdered on the soil surface in the amount of $30 \mathrm{~g} \mathrm{~m}^{2}$ then mixed with the soil by forking to a depth between 5 and $10 \mathrm{~cm}$ before solarization. The soil type is sandy with 55 percent sand, 16 percent silt \& clay. The soil $\mathrm{pH}$ ranges from 7.6 to 7.9 , electric conductivity ranged from 1.98 to $2.02 \mathrm{dSm}^{-1}$ and organic matter ranges from 2.1 to $2.3 \%$.

\section{Soil solarization and soil temperature}

The plot was prepared by tilling and crumbling to a depth of 15 to $25 \mathrm{~cm}$ and watered to field capacity. This was accomplished by covering moist soil with $0.9 \mathrm{~mm}$ thick transparent polyethylene sheets on 1st of July 2003, and the unmulched plot was left exposed to direct sun light. Edges of the polyethylene sheets were buried to $25 \mathrm{~cm}$ depth at the margins with special care to minimize the distance between the sheets and soil to prevent the formation of air pockets that retard the soil heating process. Five sections were solarized for 8 weeks and soil temperatures, minimum and maximum, were daily recorded for mulched and unmulched soil at the depths of 5 and $10 \mathrm{~cm}$ by using a soil thermometer.

\section{Soil sampling and isolation of fungi}

After solarization for eight weeks, samples were taken from the upper $20 \mathrm{~cm}$ of the soil profile with a sampling tube (ca $2.5 \mathrm{~cm}$ diameter). Five soil samples were collected at random from each section and kept in plastic bags to form composite. Total mycobiota was isolated using dilution plate method (Johnson et al 1960) in both mulched and unmulched plots. Czapek's agar supplemented with $0.5 \%$ yeast extract (CYA), amended with rose bengal (1/15000) and chloramphenicol (50 ppm) was used for primary isolation. Twenty five plates were used for each sample. Plates were incubated at $28{ }^{\circ} \mathrm{C}$ for 10 days and developing fungi were counted. For maintaining cultures and for proper identification, pure cultures of isolated fungi were grown on standard media such as Vegetable Agar (V8), Oatmeal Agar (OA), Malt Extract Agar (MEA) Potato Dextrose Agar (PDA) and Potato Carrot Agar (PCA).

Taxonomic identification by morphology of fungal isolates was mainly based on the following identification keys: Raper \& Thom (1949) and Pitt (1980) for Penicillium; Raper \& Fennell (1965) for Aspergillus; Ellis (1971 and 1976) for dematiaceous hyphomycetes; Booth (1971) for Fusarium; Arx (1981), Domsch et al (1980) for miscellaneous fungi; Arx et al (1986), Cannon (1986) for Chaetomium. The systematic arrangement follows the latest system of classification appearing in the $9^{\text {th }}$ edition of Anisworth \& Bisby's Dictionary of the fungi (Kirk et al 2001).

\section{Preparation of inocula}

\section{a- The pathogen}

Sclerotia of $M$. phaseolina were initially isolated from naturally infected sesame plant. Infected stem of sesame plants were surface sterilized using $7 \%$ sodium hypochlorite for three minutes then soaked in $55-75 \%$ ethanol for two minutes (Royse \& Ries, 1978 and Melgarejo et al 1985). After rinsing with sterilized water, stem were sliced and transferred to plates of PDA, CYA amended with rose bengal and incubated at 30c for 7 days. Microsclerotia were collected from a culture of the pathogen grown on PDA for 10 days and kept at $7{ }^{\circ} \mathrm{C}$ till use. Inoculum for use in field 
experiments was prepared by culturing the fungus in autoclaved barley grains (250 $\mathrm{g}$ of barley; $30 \mathrm{ml}$ water) at $30{ }^{\circ} \mathrm{C}$ for two weeks in $500 \mathrm{ml}$ conical flask.

\section{b- The antagonists}

Preparation of Trichoderma and Emericella cultures.

The antagonistic abilities of various isolated taxa against $M$. phaseolina were characterized by the BioControl Index (BCI) values calculated according to Leitgeb et al (2005). Due to the high rate of recolonization of $T$. pseudokoningii (Hermosa et al 2000) and high antagonistic potentiali- ty of E. nidulans they were selected for field studies. T. pseudokoningii and E. nidulans were grown on PDA for 10 days; spores of dried cultures were harvested by gentle scraping with a camel's hair brush from the dry agar surface into sterile vials containing surface sterilized, dry sesame seeds. Vials were shaken for 10 minutes to assure thorough dressing. Uncoated seeds were also used as control. Sections of both solarized and unsolarized soil were treated with fungal antagonists and $E u$ calyptus leaves as shown in Figure (1). These sections were planted by coated sesame seeds by spreading the seeds on soil surface at the rate of $500-600 \mathrm{seed} / \mathrm{m}^{2}$ then forking to a depth of 2 to 3 $\mathrm{cm}$.
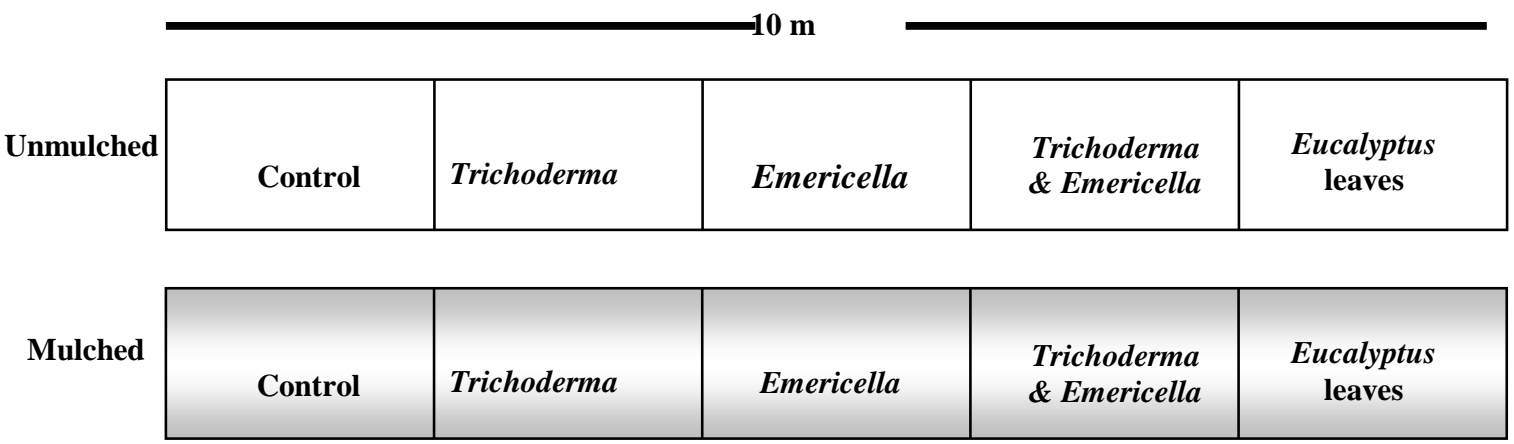

Figure 1. Experiment design and different treatments

\section{RESULTS}

\section{Efficacy of solarization}

Recorded data indicated that soil temperature during July-August elevated remarkably in solarized soil than in unsolarized at both depths (Table 1). Mulching increased average maximum soil temperature than unmulched one by $14.7{ }^{\circ} \mathrm{C}$ and $6.2{ }^{\circ} \mathrm{C}$ at 5 and $10 \mathrm{~cm}$ depths, respectively. At the depth of $5 \mathrm{~cm}$, the mean of the maximum temperatures recorded in the solarized treatment was 48.2 $+0.7^{\circ} \mathrm{C}$ while in unsolarized treatment it was 37.4 $+0.9^{\circ} \mathrm{C}$. While at the depth of $10 \mathrm{~cm}$ the mean of the maximum temperature in solarized soil was $40.4+0.5^{\circ} \mathrm{C}$ and it was $33.02+0.9^{\circ} \mathrm{C}$ in unsolarized soil with the maximum absolute temperature of $56.1^{\circ} \mathrm{C}$ in solarized and $41.2{ }^{\circ} \mathrm{C}$ in unsolarized soil respectively.

\section{Total mycobiota}

The mycobiota of unmulched and mulched plots contained a total of 54 species (16621 iso- lates): Zygomycota (eight species, 3.89\% of the total isolate number), teleomorphic Ascomycota (14 species, 8.76\%), anamorphic (asexual) Ascomycota (24 species, $83.49 \%$ ) and mitosporic fungi (8 species, $3.86 \%$ ) (Table 2).

Isolated species belonged to thirty-seven genera. The prevailing genera were Aspergillus (8 species including anamorph stages of one Emericella, two Eurotium and one Neosartorya species; $48.95 \%$ ), Chaetomium (four species; $2.47 \%$ ), Penicillium (four species including anamorph of one Talaromyces species; 1.1\%) and Fusarium (three species, $6.9 \%$ ).

The most abundant species were: Scopulariopsis brevicaulis $(26.26 \%$ of the total isolate number), Aspergillus versicolor (25.53\%), A. terreus (11.8\%), A. flavus (7.44 \%) and Fusarium oxysporum $(4.81 \%)$. Forty-nine species were isolated from unsolarized soil, while thirty-eight were recovered from solarized plots. Thirty species were common for both unsolarized and solarized plots. 
Table 1. Soil temperatures $\left({ }^{\circ} \mathrm{C}\right)$ during solarization from $1^{\text {st }}$ July to $25^{\text {th }}$ August 2003 at the study area

\begin{tabular}{|lccccccccc|}
\hline \multirow{3}{*}{ Week } & Depths & \multicolumn{9}{c|}{ Treatments } \\
\cline { 2 - 9 } & & \multicolumn{9}{c}{ Mulched } & \multicolumn{4}{c}{ Unmulched } \\
\cline { 2 - 9 } First & (Cms) & Max. & Min. & Av. & *T.F.A. & Max. & Min. & Av. & *T.F.A. \\
& 5 & 43.1 & 36.6 & 41.2 & 6.5 & 39.2 & 31.9 & 33.8 & 7.3 \\
Second & 10 & 39.7 & 34.8 & 37.3 & 4.9 & 36.7 & 29.3 & 30.6 & 7.4 \\
& 5 & 45.6 & 30.5 & 41.7 & 15.1 & 39.6 & 31.2 & 35.1 & 8.4 \\
Third & 10 & 41.9 & 28.9 & 37.6 & 13 & 36.8 & 29 & 30.9 & 7.8 \\
& 5 & 49.2 & 44.3 & 45.2 & 4.9 & 40.2 & 32.6 & 36.9 & 7.6 \\
Fourth & 10 & 45 & 39 & 41.1 & 6 & 37.1 & 31.3 & 32.5 & 5.8 \\
& 5 & 53.4 & 47.9 & 48.6 & 5.5 & 40.7 & 31.9 & 38.2 & 8.8 \\
Fifth & 10 & $\leq \vee .7$ & 39.9 & 43.5 & 7.8 & 37.4 & 30.6 & 33.1 & 6.8 \\
& 5 & 56.1 & 49.6 & 55.9 & 6.5 & 41.2 & 35.3 & 40.7 & 5.9 \\
Sixth & 10 & 44.7 & 39.3 & 41.1 & 5.4 & 37.4 & 32.1 & 34.5 & 5.3 \\
& 5 & 52.9 & 44.3 & 50.9 & 8.6 & 40.2 & 33 & 38.4 & 7.2 \\
Seventh & 10 & 43.2 & 39.6 & 40.7 & 3.6 & 36.9 & 29.9 & 33.8 & 7 \\
Eighth & 5 & 54.2 & 48.3 & 51.4 & 5.9 & 41 & 34.9 & 38.9 & 6.1 \\
& 10 & 42 & 38.1 & 41.6 & 3.9 & 38 & 30.3 & 34.7 & 7.7 \\
& 5 & 54.9 & 40.9 & 50.7 & 14 & 40.8 & 32.7 & 37.9 & 8.1 \\
& 10 & 46.1 & 37.9 & 40.9 & 8.2 & 36.5 & 29.6 & 34.1 & 6.9 \\
\hline
\end{tabular}

* Temperature fluctuation amplitude (TFA) is the difference between averages of minimum and maximum daily temperatures

Table 2. Total count (TC, colonies/g dry soil), number of cases of isolation (NCI, out of 25 soil samples) and percentage frequency of fungal taxa recovered on Czapek's yeast extract agar at $28^{\circ} \mathrm{C}$.

\begin{tabular}{|c|c|c|c|c|c|c|}
\hline \multirow[b]{2}{*}{ Species } & \multicolumn{3}{|c|}{ Unsolarized } & \multicolumn{3}{|c|}{ Solarized } \\
\hline & TC & NC1 & $\% \mathrm{~F}$ & TC & NC1 & $\% \mathrm{~F}$ \\
\hline \multicolumn{7}{|l|}{ Zygomycota } \\
\hline Absidia glauca Hagem & 0 & 0 & 0 & 137 & 7 & 28 \\
\hline Actinomucor elegans (Eidam) C.R. Benj. \& Hesselt. & 11 & 3 & 12 & 0 & 0 & 0 \\
\hline Cunninghamella echinulata (Thaxt.) Thaxt. Ex Blakeslee & 18 & 3 & 12 & 0 & 0 & 0 \\
\hline Mucor circinelloid Tiegh. & 21 & 5 & 20 & 9 & 2 & 8 \\
\hline M. racemosus Fresen. & 67 & 10 & 40 & 0 & 0 & 0 \\
\hline Mycocladus corymbiferus (Cohn) J.H. Mirza & 102 & 14 & 56 & 191 & 17 & 68 \\
\hline Rhizopus stolonifer var. stolonifer (Ehrenb.) Vuill. & 13 & 3 & 12 & 37 & 5 & 20 \\
\hline $\begin{array}{l}\text { Syncephalastrum racemosum Cohn ex J. Schröt. } \\
\text { Ascomycota (teleomorphic) }\end{array}$ & 41 & 7 & 28 & 0 & 0 & 0 \\
\hline Achaetomium macrosporum Rai, Wadhwani \& J.P. Tewari & 23 & 3 & 12 & 0 & 0 & 0 \\
\hline Byssochlamys nivea Westling & 42 & 7 & 28 & 63 & 8 & 32 \\
\hline Chaetomium bostrychodes Zopf & 38 & 4 & 16 & 0 & 0 & 0 \\
\hline Ch. globosum Kunze & 99 & 19 & 76 & 119 & 16 & 64 \\
\hline Ch. gracile Udagawa & 9 & 2 & 8 & 0 & 0 & 0 \\
\hline Ch. nigricolor L.M. Ames & 59 & 6 & 24 & 87 & 8 & 32 \\
\hline Emericella nidulans (Eidam) Vuill. & 117 & 16 & 64 & 339 & 19 & 76 \\
\hline Eurotium amstelodami L. Mangin & 11 & 3 & 12 & 37 & 4 & 16 \\
\hline E. chevalieri L. Mangin & 17 & 3 & 12 & 29 & 4 & 16 \\
\hline Gymnascella dankaliensis (Castell.) Currah & 0 & 0 & 0 & 78 & 5 & 20 \\
\hline Microascus cinereus Curzi & 54 & 3 & 12 & 145 & 7 & 28 \\
\hline M. trigonosporus C.W. Emmons \& B.O. Dodge & 32 & 4 & 16 & 0 & 0 & 0 \\
\hline Neosartorya fisherii (Wehmer) Malloch \& Cain & 0 & 0 & 0 & 27 & 2 & 8 \\
\hline Talaromyces flavus (Klöcker) Stolk \& Samson & 0 & 0 & 0 & 31 & 3 & 12 \\
\hline
\end{tabular}


Table 2. cont.

\begin{tabular}{|c|c|c|c|c|c|c|}
\hline \multirow{2}{*}{ Species } & \multicolumn{3}{|c|}{ Unsolarized } & \multicolumn{3}{|c|}{ Solarized } \\
\hline & TC & NC1 & $\% \mathbf{F}$ & TC & NC1 & $\% \mathrm{~F}$ \\
\hline \multicolumn{7}{|l|}{ Ascomycota (anamorphic)* } \\
\hline Acremonium implicatum (Gilman \& Abbott) W. Gams & 67 & 7 & 28 & 45 & 3 & 12 \\
\hline Alternaria alternata (Fr.) Keissl. & 87 & 11 & 44 & 43 & 3 & 12 \\
\hline Aspergillus flavus Link & 834 & 21 & 84 & 402 & 13 & 52 \\
\hline A. niger var. niger Tiegh. & 78 & 14 & 64 & 41 & 7 & 28 \\
\hline A. terreus Thom & 73 & 10 & 40 & 1889 & 21 & 84 \\
\hline A. versicolor (Vuill.) Tirab. & 1234 & 23 & 92 & 3009 & 25 & 100 \\
\hline Bipolaris spicifera (Bainier) Subram. & 13 & 2 & 8 & 0 & 0 & 0 \\
\hline B. indica J.N. Rai, Wadhwani \& J.P. Tewari & 27 & 5 & 20 & 0 & 0 & 0 \\
\hline Botrytis cinerea Pers. & 19 & 4 & 16 & 0 & 0 & 0 \\
\hline Cephaliophora irregularis Thaxt. & 58 & 8 & 32 & 32 & 3 & 12 \\
\hline Cladosporium herbarum (Pers.) Link & 11 & 3 & 12 & 8 & 1 & 4 \\
\hline C. sphaerospermum Penz. & 14 & 3 & 12 & 0 & 0 & 0 \\
\hline Curvularia oryzae Bugnic. & 23 & 4 & 16 & 0 & 0 & 0 \\
\hline C. tuberculata B.L. Jain & 33 & 4 & 16 & 0 & 0 & 0 \\
\hline Drechslera rostrata (Drechsler) Richardson \& E.M. Fraser & 31 & 4 & 16 & 0 & 0 & 0 \\
\hline Fusarium equiseti (Corda) Sacc. & 18 & 2 & 8 & 0 & 0 & 0 \\
\hline F. oxysporum Schltdl. & 129 & 15 & 60 & 670 & 17 & 68 \\
\hline F. solani (Mart.) Sacc. & 97 & 12 & 48 & 233 & 14 & 56 \\
\hline $\begin{array}{l}\text { Clonostachys rosea f. rosea (Link) Schroers, Samuels, } \\
\text { Seifert \& W. Gams }\end{array}$ & 28 & 4 & 16 & 66 & 6 & 24 \\
\hline Paecilomyces varioti Bainier & 17 & 2 & 8 & 31 & 3 & 12 \\
\hline Penicillium brevicompactum Dierckx & 23 & 3 & 12 & 29 & 3 & 12 \\
\hline P. chrysogenum var. chrysogenum Thom & 23 & 16 & 64 & 33 & 4 & 16 \\
\hline P. citrinum Thom & 16 & 1 & 4 & 28 & 2 & 8 \\
\hline Scopulariopsis brevicaulis (Sacc.) Bainier & 1189 & 18 & 72 & 3176 & 24 & 96 \\
\hline \multicolumn{7}{|l|}{ Mitosporic fungi } \\
\hline Acrophialophora fusispora (S.B. Saksena) Samson & 0 & 0 & 0 & 64 & 6 & 24 \\
\hline Epicoccum nigrum Link & 3 & 1 & 4 & 0 & 0 & 0 \\
\hline Humicola fuscoatra Traaen & 49 & 5 & 20 & 81 & 5 & 20 \\
\hline Macrophomina phaseolina (Tassi) Goid. & 21 & 2 & 8 & 0 & 0 & 0 \\
\hline Microdochium dimerum (Penz.) Arx & 36 & 4 & 16 & 0 & 0 & 0 \\
\hline Myrothecium roridum Tode & 177 & 7 & 28 & 79 & 5 & 20 \\
\hline Stachybotrys chartarum (Ehrenb.) S. Hughes & 8 & 2 & 8 & 9 & 1 & 4 \\
\hline Trichoderma pseudokoningii Rifai & 83 & 10 & 40 & 21 & 5 & 20 \\
\hline Total & 5293 & & & 11328 & & \\
\hline
\end{tabular}

* According to the system of Kirk et al (2001).

Effect of fungal antagonists and soil amendment on disease reduction

In vitro both of T. pseudokoningii and E. nidulans recorded a high percentage of frequency among all isolated taxa (Table 3). The growth of the pathogen, $M$. phaseolina, reached $4.5 \mathrm{~cm}$ in four days and by the 7th day of inoculation, the whole plate was covered. The data of Table 3 re- veals the BCIs for the in vitro antagonism tests performed on two different media. Data clearly show that BioControl Index (BCI) of T. pseudokoningii on both media, PDA and CYA, is higher than that of E. nidulans.

In field studies, the count of healthy plants in percentage by using fungal candidates in unsolarized soil varies, while $T$. pseudokoningii revealed $83 \% \pm 0.8$ plant, E. nidulans showed $55 \% \pm 0.5$. In 
case of mixed inocula (T. pseudokoningii \& E. nidulans) the number of healthy plants was $75 \% \pm$ 3.2.

In solarized soils, on the other hand, while the percentage of healthy plants recorded by using of T. pseudokoningii was $91 \% \pm 0.6$, it was $82 \% \pm 2.1$ in case of using E. nidulans. By mixing of $T$. pseudokoningii and E. nidulans the number of healthy plants was $85 \% \pm 2.5$. In solarized soil, $77 \%+1.2$ of the soil amendment treated plants were healthy in comparison with $65 \% \pm 0.7$ in unsolarized treatments.

Table 3. In vitro (BCIs) for the two antagonists and in vivo the percentage of health plants with different treatments in both mulched and unmulched soil.

\begin{tabular}{|cccc|}
\hline & \multicolumn{1}{c}{ Species } & BCI (PDA) & BCI (CYA) \\
\hline \multirow{4}{*}{ In vitro } & T. pseudokoningii & $75 \pm 0.7$ & $71 \pm 0.4$ \\
& E. nidulans & $62 \pm 0.8$ & $58 \pm 0.3$ \\
\hline \multirow{4}{*}{ In vivo } & \multicolumn{2}{c}{ Healthy Plants \% } \\
\cline { 2 - 4 } & Treatments & Unsolarized & Solarized soil \\
& & soil & \\
& T. pseudokoningii & $83 \% \pm 0.8$ & $91 \% \pm 0.6$ \\
& E. nidulans & $55 \% \pm 0.5$ & $82 \% \pm 2.1$ \\
& Mixed inocula & $75 \% \pm 3.2$ & $85 \% \pm 2.5$ \\
& Soil amendment & $65 \% \pm 0.7$ & $77 \% \pm 1.2$ \\
\hline
\end{tabular}

\section{DISCUSSION}

Soil solarization provided effective control of many soil borne diseases as well as charcoal rot of sesame. Soil solarization (8 weeks from JulyAugust of soil mulching with transparent polyethylene sheets) reduced disease incidence throughout the cropping season. Our data on soil solarization, as a single control measure, clearly indicated that this approach apart from being feasible is very effective. The number of healthy plants significantly increased from $30 \%$ in unsolarized soil up to $80 \%$ in solarized soil. This level of increase for M. phaseolina is very much acceptable. Similar results of increase of disease control have also been reported in some other countries like: USA (Stapleton, 1991), occupied Palestine (Grinstein and Ausher, 1991), India (Lodha, 1995; Lodha et al 1997), Pakistan (Ahmad et al 1996) and UK (Pinkerton et al 2000).
Maximum temperatures obtained at the layer $5-1 \cdot \mathrm{cm}$ of the mulched soil $\left(57^{\circ} \mathrm{C}-47.5^{\circ} \mathrm{C}\right)$ were in the range considered by many workers to be lethal to many soil fungi. De Vay (1990); Stapleton (1990) and Keinath (1995) reported that temperatures at $47^{\circ} \mathrm{C}$ or higher are lethal to many mesophilic fungi.

Soil solarization in combination with fungal antagonists has been subjected to control of charcoal rot of sesame caused by $M$. phaseolina. Such a combination might further enhance the long term supperssiveness of solarized soil. Whenever a pathogen is weakened by one treatment, a synergistic effect may be possible from double treatment. Such improvement in the antagonistic activity and accordingly the biocontrol potentiality might refer to a development of some sort of synergistic effect upon using single inocula plus soil solarization as mentioned by various investigators viz: Elad et al 1981 and Ristaino et al 1991.

The efficiency of solarization plus coating with pair inocula was tested in a trial to assess its efficiency to control charcoal rot under field conditions. The data of this experiment (mixing of $T$. pseudokoningii plus E. nidulans) showed that while pairing improved the biocontrol potentiality of $E$. nidulans by increasing the number of healthy plants in both unsolarized and solarized soils it leads to decrease in the biocontrol potentiality of T. pseudokoningii i.e. the number of healthy plants revealed by the pair is less than that obtained by $T$. pseudokoningii alone in unsolarized and solarized soils.

Where solarization plus soil amendments with Eucalyptus leaves were tested in a trial to manage charcoal rot of sesame under field conditions, the data showed that solarization improved the effect of soil amendment with Eucalyptus leaves by increasing the number of healthy plants. According to phytochemical investigations, the all promising extracts partaked in phenolic glycosides, sterols and/or triterpenes besides to pyrgallol tannins, saponins glycosides and alkaloids. As a bioactive agent against insect, nematode and microbial agents our results are in agreement with other investigations carried by Sarvamangala \& Govindaiah Datta (1993) and Johnson (2005).

In view of the data obtained, it seems likely that solarization lie in its high efficacy and safety in the economical control of a wide array of soil borne pathogens. Such feasibility of solarization may be improved by integrated disease management with other control measures for controlling charcoal rot of sesame. 


\section{ACKNOWLEDGMENT}

We would like to express our appreciation to Prof. A. F. Moustafa (Botany Department, Faculty of Science, Suez Canal university) for reviewing the manuscript.

\section{REFERENCES}

Ahmad, Y.; A. Hameed and M. Islam (1996). Effect of soil solarization on corn stalk rot. Plant and Soil 179 (1): 17-24.

Ali, M.Z; I. Waseem; A. Kader and M.Mayof (1990). Control of soil borne pathogens with soil solarization in the southern region of Libyan Jamahiriya. Proceedings of the First International Conference on Soil Solarization. Amman, Jordan, FAO, 213-219.

Arx, J. A. von (1981). The Genera of Fungi Sporulating in Pure Culture. J. Cramer, Vaduz, Berlin. $2^{\text {nd }}$ Ed. 315 pp.

Arx, J.A. Von; J. Guarro and M.J. Figueras (1986). The ascomycete genus Chaetomium. Nova Hedwigia Beiheft 14: 1-162.

Booth, C. (1971). The Genus Fusarium. Commonwealth Mycological Institute, Kew, Surrey, England. 237 pp.

Cannon, P.F. (1986). A revision of Achaetomium, Achaetomiella and Subramaniula, and some similar species of Chaetomium. Transactions of the British Mycological Society 87:45-76.

Chellemi, D.O.; S.M. Olson; D.J. Mitchell; I. Seckers and R. McSorley (1997). Adaptation of soil solarization to the integrated management of soil borne pests of tomato under humid conditions. Phytopathology, 87(3): 250-258.

Cloud, G.L. and J.C. Rupe (1991). Comparison of three media for enumerication of sclerotia of Macrophomina phaseolina. Plant Disease 75: 771-772.

Davis, J.R. (1991). Soil solarization: pathogen and disease control increases in crop yield and quality: short-and long term effects and integrated control. (In: Katan J. and J. E. De Vay (eds.), Soil Solarization (pp. 39-50). CRC Press, Boca Raton, Florida).

De Vay J.E. (1990). Historical review and principles of soil solarization. (In: De Vay, J.E.; J. Stapleton and C.L. Elmore (eds.), Soil Solarization No. 78 (pp. 2-15). FAO Plant Production and Protection Paper 109, Rome, 1990.

Domsch, K.H.; W. Gams and T.H. Anderson (1980). Compendium of Soil Fungi. Academic
Press. Vol. I, 859 pp. and II, 405 pp., LTD, London.

Elad, Y.; Y. Hadar; E. Hadar; I. Chet and Y. Henis (1981). Biological control of Rhizoctonia solani by Trichoderma harzianum in carnation. Plant Disease, 65: 675-677.

Ellis, M.B. (1971). Dematiaceous Hyphomycetes. 608 pp. Commonwealth Mycological Institute, Kew, Surrey, England.

Ellis, M.B. (1976). More Dematiaceous Нyphomycetes. 507 pp. Commonwealth Mycological Institute, Kew, Surrey, England.

Grinstein, A. and R. Ausher (1991). Soil solarization in Israel. (In: Katan J. and De Vay J.E. (eds.). Soil Solarization (pp. 159-170), CRC Press, Boca Raton Florida.

Hermosa, M.R.; I. Grondona; E. A. Iturriaga; J. M. Díaz-Mínguez; C. Castro; E. Monte and I.García-Acha (2000). Molecular characterization and identification of biocontrol isolates of Trichoderma spp. Applied Environmental Microbioliolg, 66: 1890-1898.

Johnson, M.L. (2005). Investigating Alternatives for Control of Phalaris arundinacea (Reed Canary grass) in Urban Wetlands. p. 32. Master in Environmental Management, Portland State University, Oregon, USA.

Johnson, L; E. Curl; J. Bond and H. Fribourg (1960). Methods for Studying Soil MicrofloraPlant Disease Relationships. pp. 178. Burgess Publishing Company, Minneapolis.

Katan, J. (1981). Solar heating (solarization) of soil for control of soilborne pests. Annual Review of Phytopathology. 19: 211-36.

Keinath, A.P. (1995). Reductions in inoculum density of Rhizoctonia solani and control of belly rot on pickling cucumber with soil solarization. Plant Disease 79:1213-1219.

Kirk, P.M.; P.F. Cannon; J.C. David and J.A. Stalpers (eds.) (2001). Ainsworth \& Bisby's Dictionary of the Fungi, $9^{\text {th }}$ Edition. CAB International,198. Madison Avenue, NewYork, USA.

Leitgeb, B; L. Kredics; A. Szekeres; L. Manczinger and C. Vágvölgyi (2005). An in vitro method for the characterization of biocontrol abilities. Journal of Biotechnology, 118(S1): 172.

Lodha, S. (1995). Soil solarization, summer irrigation and amendments for the control of Fusarium oxysporum f. sp. cumini and Macrophomina phaseolina in arid soils. Crop Protection 14(3): 215-2129.

Lodha, S.; S. Sharma and R.K. Aggarwal (1997). Solarization and natural heating of irrigat- 
ed soil amended with cruciferous residues for improved control of Macrophomina phaseolina. Plant Pathology 46: 186-190.

Melero-Vara, J.M.; M.A. Blanco-Lopez; J. Bejarano-Alcarar and R.M. Jimenez-Diaz (1995). Control of Verticillium wilt of cotton by means of soil solarization tolerant cultivars in Southern Spain. Plant Pathology 44: 250-260.

Melgarejo, P; R. M. Carrillo and E.Sagasta (1985). Mycoflora of peach twigs and flowers and its possible significance in biological control of Monilinia laxa. Transactions of the British Mycological Society 85(2): 313-317.

Mihail, J.D. and S.J. Taylor (1995). Interpreting variability among isolates of Macrophomina phaseolina in pathogenicity, pycnidium production, and chlorate utilization. Canadian Journal of Botany 73: 1596-1603.

Osman, A.A. (1990). The role of soil solarization in the scope of Meloidogyne spp. Integrated control under sandy soil conditions. pp. 189-194. (In: De Vay, J.E.; J.J. Stapleton and C.L. Elmore (eds), Proceeding of the First Int. Conference on Soil Solarization. Amman, Jordan, 19-25 February 1990. FAO Plant Protection and Production Paper No. 109. Rome, 1990.

Pinkerton, J.N.; K.L. Ivores; M.L. Miller and L.W. Moore (2000). Effect of soil solarization and cover crops on population of selected soilborne plant pathogens in Western Oregon. Plant Disease 89: 952-960.

Pitt, J. (1980). The Genus Penicillium. 423 pp., Academic Press, New York.

Ramirez-Villapudua, J. and D.E. Munnecke (1988). Effect of solar heating and soil amendments of cruciferous residues on Fusarium oxysporum f. sp. conglutinans and other organisms. Phytopathology, 78: 289-295.

Raper, K.B. and D.I. Fennell (1965). The Genus Aspergillus. Williams and Wilkins Co. Baltimore. IX + 686 pp.

Raper, K.B. and C. Thom (1949). A Manual of the Penicillia. Williams and Wilkins Co. Baltimore. IX + 875 pp.

Ristaino, J.B; K.B. Perry and R.D. Lumsden (1991). Effect of solarization and Gliocladium virens on sclerotia of Sclerotium roffsii, soil microbiota, and the incidence of southern blight of tomato. Phytopathology, 81: 1117-1124.

Royse, D.J. and S.M. Ries (1978). The influence of fungi isolated from peach twigs on the pathogenicity of Cytospora cinta. Phytopathology 68: 603-607.

Sarhan, A.R.T. (1990). Control of Fusarium solani in broad bean by solar heating of the soil in northen Iraq. Proceeding of the First International Conference on Soil Solarization. pp 108117. Amman, Jordan.

Sarvamangala, H.S. and R.K. Govindaiah Datta (1993). Evaluation of plant extracts for the control of fungal diseases of mulberry. Indian Phytopathol. 46: 398-401.

Satour, M.M; M.F. Abdel-Rahim; T. ElYamani; A. Radwan; A. Grinstein; H.D. Rabinowitchand J. Katan (1989). Soil solarization in onion fields in Egypt and Israel: short and long term effects. Acta Horticulturae 255: 151161.

Srivastava, A.K; T. Singh; T.K. Jana and D.K. Arora (2001). Microbial colonization of Macrophomina phaseolina and suppression of charcoal rot of chickpea. (In: Sinha, A. (eds.), Microbes and Plants (pp 269-319), Vedams eBooks (P) Ltd., New Delhi.

Stapleton, J.J. (1990). Physical effects of soil solarization-thermal inactivation of crop pests and pathogens and other soil changes caused by solarization. (In: De Vay, J.E.; J.J. Stapleton and C.L. Elmore (eds), Proceeding of the First Int. Conference on Soil Solarization. pp. 37-47. FAO Plant Protection and Production Paper No. 109. Rome, 1990. Amman, Jordan, 19-25 February 1990.

Washington, O; T. Aad; J. Mike and O.O. Caleb (2003). Efficacy of soil solarization, Trichoderma harzianum, and coffee pulp amendment against Armillaria sp. Crop Protection 22 (3): 325-331.

Wyllie, T.D. (1988). Charcoal rot of soybeancurrent status. (In: Wyllie T.D. and D.H. Scott (eds.), Soybean Diseases of North Central Region). pp. 315 - 331. APS Press, St. Paul, MN 